\title{
Impact of various endocrine and paracrine factors on in vitro culture of preantral follicles in rodents
}

\author{
I Demeestere ${ }^{1}$, J Centner ${ }^{1}$, C Gervy ${ }^{2}$, Y Englert ${ }^{1,3}$ and A Delbaere ${ }^{1,3}$ \\ ${ }^{1}$ Research Laboratory on Human Reproduction, ${ }^{2}$ Laboratory of Chemistry and ${ }^{3}$ Department of Obstetrics and \\ Gynaecology, French Speaking Free University of Brussels (ULB), Campus Erasme (GE-niv 2), 808 Route de Lennik, \\ 1070 Brussels, Belgium
}

Correspondence should be addressed to I Demeestere; Email: idemeest@ulb.ac.be

\begin{abstract}
Folliculogenesis is a complex process regulated by various paracrine and autocrine factors. In vitro growth systems of primordial and preantral follicles have been developed for future use of immature oocytes, as sources of fertilizable oocytes and for studying follicular growth and oocyte maturation mechanisms. Rodents were often chosen for in vitro follicular culture research and a lot of factors implicated in folliculogenesis have been identified using this model. To date, the mouse is the only species in which the whole process of follicular growth, oocyte maturation, fertilization and embryo transfer into recipient females was successfully performed. However, the efficiency of in vitro culture systems must still be considerably improved. Within the follicle, numerous events affect cell proliferation and the acquisition of oocyte developmental competency in vitro, including interactions between the follicular cells and the oocyte, and the composition of the culture medium. Effects of the acting factors depend on the stage of follicle development, the culture system used and the species. This paper reviews the action of endocrine, paracrine factors and other components of culture medium on in vitro growth of preantral follicles in rodents.
\end{abstract}

Reproduction (2005) 130 147-156

\section{Introduction}

Several endocrine and locally acting factors are involved during the complex process of ovarian follicular growth and oocyte maturation. In vitro follicular culture systems at various developmental stages allow the identification of these factors and the understanding of their mechanisms of action.

The development of in vitro follicular culture systems has not only had a major impact on ovarian physiological research but also on clinical practice. An efficient human ovarian tissue culture system could profoundly modify the treatment options for infertile couples by avoiding the need of intensive ovarian stimulation. Indeed, several hundred primordial and primary follicles can be obtained after a single ovarian biopsy in a young woman, which is enough to attempt several in vitro follicular cultures and oocyte maturation procedures. Optimal in vitro follicular culture models should result in competent mature oocytes that could be fertilized to obtain viable embryos. Another important outcome is to preserve the fertility of young woman at risk of premature ovarian failure by long-term storage of female germ-cells (Hardy et al. 2002, Demeestere et al. 2003): frozen-thawed ovarian tissue can later be used to restore their fertility. In this case, follicular development can be supported in vitro, thanks to follicular culture techniques, or in vivo, thanks to autotransplantation techniques. However, both procedures require improvement before clinical application becomes routine.

Identification of factors promoting follicular growth and development or inducing atresia constitutes one of the main objectives of the research program on folliculogenesis. To date, the rodent model is the most advanced system for studying in vitro follicular development. At present, the mouse is the only species for which a complete in vitro culture process has been achieved from the primordial stage up to live offspring (Eppig \& O'Brien 1996, O'Brien et al. 2003).

Rodent models present several advantages. As in humans, the follicular growth includes two different periods: a gonadotropin-independent and gonadotropindependent period. The development of the preantral follicles until the preovulatory stage spreads over a period of 85 days in humans (Gougeon 1996). The improvement of in vitro culture systems and the expansion of our knowledge of follicular biology are very difficult to achieve over such a long period of in vitro growth. In mice, this growth phase is completed within 10-12 days 
in vitro. Furthermore, the isolation of the preantral follicles is easier in mice compared with humans due to the high density of the cortex in humans. The size and the total number of follicles are smaller in rodents $(5000 \mathrm{vs}$ 200000 follicles in total in prepubertal ovaries from mice and humans respectively), but the fraction of follicles in growth phase is considerably higher, facilitating the isolation of a homogeneous population of growing follicles. The fraction of growing follicles is around 0.1 in adult mice, compared with 0.04 in humans (Gosden et al. 1993). Finally, much of our understanding of oocyte growth factors such as the growth differentiation factor-9 (GDF-9) or the bone morphogenic protein-15 (BMP-15) comes from experiments on rodents and has now been confirmed in humans (Erickson \& Shimasaki 2001). The possibility to create mice deficient for specific genes represents considerably useful models for studying the impact of different factors on folliculogenesis. At last, the well-characterized technical aspects and the high reproducibility of results has lead to the consideration of the preantral follicles culture system as a model for screening potentially ovotoxic substances (Cortvrindt \& Smitz 2002).

Thus, despite some major differences in ovarian physiology between rodents and humans, mice constitute a relevant model for identifying the endocrine and local mechanisms controlling follicular development.

\section{Follicular culture systems in mice}

Several in vitro culture systems of preantral follicles from rodents have been developed leading to the production of fully competent oocytes and viable offspring (Roy \& Greenwald 1985, Eppig \& Schroeder 1989, Nayudu \& Osborn 1992, Cortvrindt et al. 1996).

These different culture systems have a common step the isolation of preantral follicles from the ovary. Preantral follicles can be isolated mechanically or enzymatically (Eppig \& Schroeder 1989, Demeestere et al. 2002). The isolation of preantral follicles using enzymes presents the advantage of collecting a large number of follicles per ovary. This technique also facilitates the procedure when ovarian cortex is dense as is the case in large mammals and humans (Roy \& Treacy 1993). However, follicle integrity is not preserved and the structure is reduced to oocyte-granulosa-cell complexes (OGC) with an oocyte surrounded by one to three layers of granulosa cells (GCs) (Eppig \& Schroeder 1989). In contrast, mechanical isolation of follicles allows intact preantral follicles to be obtained with a centrally located oocyte surrounded by two or three layers of membrane enclosed GCs and some theca cells attached to the basal membrane (Cortvrindt et al. 1996). The preantral follicles selected for in vitro culture generally measure $100-130 \mu \mathrm{m}$ diameter in mice (Cortvrindt et al. 1996) and $130-160 \mu \mathrm{m}$ in rats (McGee et al. 1999, Zhao et al. 2001a).
Isolated follicles have been cultured in systems that preserved the spherical follicular structure or in contrast, attached to a support. In spherical follicular culture systems, the follicles grow embedded within a collagen matrix (Torrance et al. 1989) or in non-adherent conditions (Nayudu \& Osborn 1992). Both intact follicles and OGC can also be cultured on collagen-impregnated membranes (Eppig et al. 1996) or attached to the dishes (Cortvrindt et al. 1996).

Thus, different models of follicular culture have led to competent fertilizable oocytes after in vitro growth and maturation in mice. The choice of the culture system depends on the aim of the experiments and always involves some compromises (Smitz \& Cortvrindt 2002). Furthermore, the effect of endocrine and locally acting factors described during in vitro follicular development varies regarding the culture system used and the species.

Based on the literature and on personal data, this manuscript focuses on the effect of some endocrine and paracrine factors on preantral follicular growth and differentiation during in vitro follicular culture using the rodent model.

\section{Gonadotropins}

The major endocrine factors that modulate follicular development are gonadotropins, namely follicle stimulating hormone $(\mathrm{FSH})$ and luteinizing hormone $(\mathrm{LH})$.

LH plays a key role in stimulating the enzymes responsible for androgen production in the theca cells and in initiating the final differentiation of the GCs. During ovulation, the LH surge induces a cascade of events leading to the resumption of meiotic maturation, the luteinization of the GCs, the expansion of the cumulus cells and finally the rupture of the follicle wall. Recently, it has been suggested that the action of LH during the ovulation process could be mediated by paracrine factors, members of the epidermal growth factor (EGF) family (Park et al. 2004, Ashkenazi et al. 2005). In LH receptor knockout mice (LuRKO) or LH $\beta$-subunit deficient mice, females are infertile. Follicles are able to reach the antral stage but they then degenerate (Zhang et al. 2001, Ma et al. 2004). This glycoprotein hormone is not essential to complete follicular development in vitro. However, the addition of low concentrations of $\mathrm{LH}$ during in vitro follicular culture enhances the antral cavity formation and improves the oocyte's meiotic maturation (Cortvrindt et al. 1998).

The essential role of FSH during antral follicular growth in vivo is well established. In $\mathrm{FSH} \beta$ deficient mice or $\mathrm{FSH}$ receptor knockout mice (FORKO), females are infertile (Kumar et al. 1997, Abel et al. 2000). All follicular stages, up to the preantral stage were observed but no further follicular development and ovulation have been described in FORKO mice. These experiments clearly indicate the essential role of $\mathrm{FSH}$ on early antral stage follicles for further growth and differentiation. 
In vivo, $\mathrm{FSH}$ is essential for the steroidogenesis by stimulating aromatase enzyme activity (P450 aromatase), for the differentiation of the granulosa cells by inducing the expression of $\mathrm{LH}$ receptors and for the follicular antrum formation. $\mathrm{FSH}$ also regulates the transzonal connection between the oocytes and the surrounding GCs (Albertini et al. 2001). Furthermore, the presence of gonadotropins induces the expression of inhibitor of apoptosis proteins (IAP) by GCs in vivo and in vitro (Wang et al. 2003). Finally, FSH interacts with several growth factors to induce follicular growth such as kit ligand (KL), EGF, activin A, inhibin, BMP-15 or insulin-like growth factor (IGF-I). These intraovarian regulators mediate the effect of gonadotropins in regulating cellular interactions by autocrine and paracrine mechanisms (Erickson \& Shimasaki 2001).

Assuming these major functions, FSH is usually added to the preantral follicular culture medium in mice and in large mammals (Nayadu \& Osborn 1992, Cortvrindt et al. 1996, Mao et al. 2002). Both pituitary and recombinant FSH $(\mathrm{rFSH})$ supported in vitro follicular growth. Liu et al. (2000) compared three different FSH preparations added during in vitro follicular growth: $\mathrm{rFSH}$, urinary purified FSH (uFSH) and human menopausal gonadotropin (HMG). HMG induced a significant increase in follicular diameter and steroids secretion compared with rFSH or $\mathrm{uFSH}$ related to the presence of $\mathrm{LH}$ in the preparation.

Cortvrindt et al. (1997) showed that a minimal concentration of $10 \mathrm{mUI} / \mathrm{ml}$ of $\mathrm{FSH}$ is essential during in vitro culture of intact preantral follicles. In the absence of $\mathrm{FSH}$, only $17 \%$ of the follicles survived. In this culture system, full differentiation of the preantral follicles in vitro can be achieved only in the presence of $\mathrm{FSH}$ at least from the late preantral stage (Adriaens et al. 2004). Using the same culture model, Mitchell et al. (2002) also reported a follicular survival rate of only $10 \%$ in the absence of $\mathrm{FSH}$ during in vitro growth. A dose-response curve for the effect of $\mathrm{FSH}$ during intact preantral follicular culture showed an increase in the follicular mean growth rate with increasing concentrations of $\mathrm{FSH}$ to a maximum of $100 \mathrm{mUI} / \mathrm{ml}$ (Nayadu \& Osborn 1992). When the follicles were cultured in the presence of $1000 \mathrm{mUI} / \mathrm{ml} \mathrm{FSH}$, the proportion of follicles ovulating was significantly lower than in the presence of $100 \mathrm{mUI} / \mathrm{ml} \mathrm{FSH}$ (Mitchell et al. 2002). Excessive exposure to $\mathrm{FSH}$ could result in $\mathrm{FSH}$ receptor down-regulation, leading to a suboptimal follicular response (LaPolt et al. 1992).

On the other hand, mice OGC have been cultured in the absence of FSH and serum up to the final oocyte maturation process (Eppig \& Shroeder 1989). The same authors even described a negative effect of FSH on the growth of OGC in the presence of insulin (Eppig et al. 1998a). However, in the same culture system but in the presence of serum, the oocyte growth was increased after culture in medium supplemented with FSH compared with culture without FSH (Eppig \& O'Brien 1998b). In accordance with these observations, studies in the rat did not show any FSH effect on the follicular development when the culture medium was not supplemented with serum. However, follicular culture with both FSH and cyclic guanosine monophosphate (cGMP), as antiapoptic factor, resulted in an increase of the follicle diameter (McGee et al. 1997). Administered with other growth factors such as IGF-I or activin A, FSH also had a significant stimulatory effect on follicular development and steroidogenesis in serum free conditions (Liu et al. 1998).

The actions of FSH during in vitro preantral follicular growth thus appear to be dependent on the culture conditions and particularly on the presence of serum in the culture medium: in the absence of serum, FSH can achieve its mitogenic and steroidogenic effects in the presence of other growth or survival factors.

Variations in the effects of $\mathrm{FSH}$ in vitro were also observed regarding the species. The addition of FSH to the culture media of porcine and bovine GCs decreased apoptosis (Guthrie et al. 1998, Yang \& Rajamahendran 2000), while FSH as well as LH or IGF-I were ineffective in the prevention of spontaneous apoptosis when added to the culture medium of isolated rat GCs (Hsueh et al. 1994). However, FSH attenuated apoptosis during in vitro culture of intact rat preovulatory follicles (Chun et al. 1994). Recently, Yacobi et al. (2004) described opposite effects of gonadotropins on apoptosis depending on the cell types: in culture of rat preovulatory follicles, the addition of FSH or LH to the serum free medium resulted in a decrease of DNA fragmentation in GCs but in an increase of DNA fragmentation in theca cells following the activation of caspase-3 and -7 , involved in the apoptosis process.

Although gonadotropins are essential factors regulating follicular development, several growth and endocrine factors locally produced by the follicles are able to amplify or attenuate FSH action (Fig. 1). One of those endocrine factors are androgens, that are produced by the theca interna and diffuse to the mural GCs where they are converted to estrogens by cytochrome P450 aromatase through FSH stimulation (Tetsuka et al. 1995). Inhibition of aromatase P450 activity during mice preantral follicular culture enhanced follicular differentiation and oocyte maturation rates. In these conditions, estradiol secretion was suppressed and androgens accumulated in the medium (Hu et al. 2002). Other authors confirmed that androgens have a direct stimulatory effect on in vitro follicular development in rodents, suggested by the absence of effect of neither the anti-estrogen nor the anti-progesterone antiserum (Murray et al. 1998).

\section{Serum and ITS (insulin, transferrin, selenium)}

Most culture systems use fetal calf serum (FCS) or hypogonadal (hpg) mouse serum (containing extremely low levels of FSH and $\mathrm{LH}$ ) as the protein source to support follicular growth in vitro. The identification of the different growth factors and carrier proteins, present in the serum and essential for follicular development, is still a challenge in 


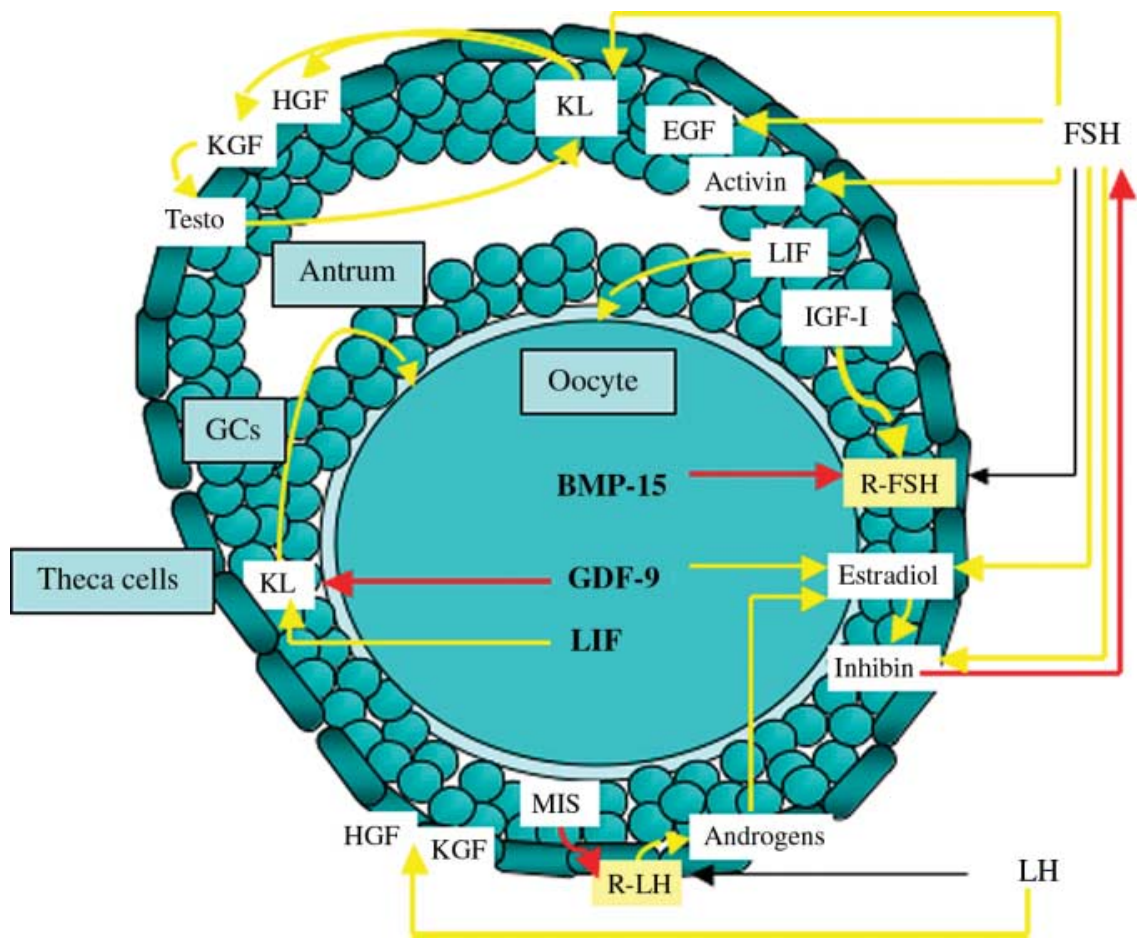

Figure 1 Factors involved in the control of follicular development: negative (red arrow) and positive (yellow arrow) effect. GDF, growth differentiation factor-9; KGF, keratinocyte growth factor; $\mathrm{GH}$, growth hormone; IGF-I, insulin growth factor-l; KL, kit ligand; LIF, leukemia inhibitory factor; EGF, epidermal growth factor; BMP-15, bone morphogenic protein-15; HGF, hepatocyte growth factor; MIS, mullerian-inhibiting substance; $\mathrm{FSH}$, follicle-stimulating hormone; LH, luteinizing hormone; $\mathrm{R}-\mathrm{LH}$ and $\mathrm{R}-\mathrm{FSH}$, receptors for $\mathrm{LH}$ and FSH; Testo, testosterone; GCs, granulosa cells.

cell culture. The presence of high concentrations of serum during preantral follicular culture constitutes inadequate conditions for in vitro physiological studies. Indeed, serum provides numerous known and unknown proteins that could interact with the other components added in the medium. Furthermore, serum should be avoided from in vitro follicular culture medium regarding further clinical application of the procedure.

Serum elimination from follicular culture medium induced apoptosis compromising the subsequent follicular development. Using an intact preantral follicle culture model, Mitchell et al. (2002) showed that all follicles cultured in human serum albumin (HSA) or normal mouse serum, degenerated after 9 days of in vitro culture. In contrast, hpg mouse serum and FCS both supported follicular growth in the presence of FSH. The follicular survival rate was not significantly different when FCS or hpg mouse serum was added to the culture medium (follicular survival rate was of 93 and $87 \%$ respectively). However, a lower proportion of oocytes were able to mature in response to human chorionic gonadotropin (hCG) when the follicles were cultured with hpg mouse serum than when cultured with FCS, suggesting on the other hand that factors lacking in the hpg mouse serum may also influence further oocyte competence.

Extrinsic and intrinsic pathways of apoptosis induction in GCs are not yet clearly defined but they include lack of growth factors, or presence of cytotoxic stimuli such as fas ligand (FasL). Previous studies showed that the presence of $\geq 1.25 \%$ of serum is enough to completely block the action of FasL (Quirk et al. 2000). Below this concentration, other factors should be added to the culture medium to reduce the apoptotic process. Different factors have been used to reduce apoptosis during follicular in vitro culture in serum free conditions (McGee et al. 1997, Eppig et al. 2000, Murray et al. 2001). Treatment of cultured rat preantral follicles with 8-bromo-cGMP did suppress apoptosis (McGee et al. 1997). However, the antiapoptotic effect of 8-bromo-cGMP was not observed in cultured mice OGC (Eppig et al. 2000).

Ascorbic acid (vitamin C) reduced apoptosis during in vitro growth of mice OGC and intact preantral follicles in serum free conditions (Eppig et al. 2000, Murray et al. 2001). Added to serum containing medium during intact bovine preantral follicular culture in a three-dimensional system, ascorbic acid also increased the percentage of follicles that maintained basement membrane integrity, demonstrating the multiple roles of this vitamin during folliculogenesis in rodents but also in domestic species (Murray et al. 2001, Thomas et al. 2001).

The standard concentration of serum added to the follicular culture medium is $5 \%$ of FCS or hpg mouse serum. Using intact preantral follicular culture model in mice, we investigated the effect of reducing the FCS concentration in the culture medium. The culture medium used for these experiments was supplemented with $\mathrm{rFSH}$, rLH and insulin, transferrin, selenium (ITS) as previously described (Demeestere et al. 2002). Reducing the concentration of serum from $5 \%$ to $1 \%$ in the culture medium did not significantly affect the follicular survival rate after 12 days of in vitro culture but decreased the oocyte maturation rate after in vitro maturation induced by hCG and EGF (Table 1). However, estradiol levels measured in the culture medium collected every 3 days were higher when 
Table 1 Effect of different media during in vitro culture of mouse preantral follicles on subsequent oocyte in vitro maturation. Intact preantral follicles were isolated from ovaries of 12-14 day-old mice and cultured in MEM supplemented with $100 \mathrm{mlU} / \mathrm{ml} \mathrm{r-FSH}$, $10 \mathrm{mlU} / \mathrm{ml} \mathrm{r}-\mathrm{LH}, 5 \mu \mathrm{g} / \mathrm{ml}$ transferrin, $5 \mathrm{ng} / \mathrm{ml}$ selenium, 0 or $5 \mu \mathrm{g} / \mathrm{ml}$ of insulin (ITS) and 1 or $5 \%$ fetal calf serum (FCS). Half of the medium was replaced every 3 days. After 12 days, culture medium was replaced by maturation medium (MEM supplemented with $\mathrm{r}$ FSH, r-LH, ITS, $1.5 \mathrm{IU} / \mathrm{ml}$ r-hCG, $5 \mathrm{ng} / \mathrm{ml}$ EGF and 5\% FCS). Oocytecumulus complexes (OCC) were collected and denuded to observe nuclear maturation stage: metaphase II (MII), germinal vesicle (GV), germinal vesicle breakdown (GVBD).

\begin{tabular}{lcccc}
\hline & \multicolumn{2}{c}{ With insulin } & & Without insulin \\
\cline { 2 - 3 } \cline { 5 - 5 } & $5 \%$ FCS & $1 \%$ FCS & & $1 \%$ FCS \\
\hline$n$ (follicles) & 99 & 100 & \\
OCC (\%) & $90(97.7)$ & $80(93)$ & & $86(96.6)$ \\
MII $(\%)$ & $75(83.3)^{\mathrm{a}}$ & $45(56.2)^{\mathrm{b}}$ & & $52(60.4)^{\mathrm{b}}$ \\
GV $(\%)$ & $2(2.2)$ & $13(16.1)$ & & $15(17.4)$ \\
GVBD $(\%)$ & $12(13.3)$ & $20(25)$ & & $20(23.2)$ \\
\hline
\end{tabular}

a vs b: $P<0.05$.

serum concentration was reduced during in vitro follicular growth. The values reached significance after 6 and 9 days of in vitro culture (data not shown). These results confirm previous studies in bovine reporting a decrease of estradiol secretion by GCs cultured into serum-coated wells compared with those cultured in serum free conditions (Gutierrez et al. 1997). The reason for the decrease of estradiol levels in the presence of serum is still unclear. However, the decrease of estradiol production in the presence of serum is not related to premature luteinization as suggested by the absence of serum effect on progesterone secretion by the GCs (Gutierrez et al. 1997).

Insulin is usually added to the culture medium at supraphysiological concentration $(5 \mu \mathrm{g} / \mathrm{ml})$ as survival factor, together with transferrin and selenium (ITS). Added to cell cultures, insulin increases the uptake of metabolic precursors as amino acids and glucose. However, Eppig et al. (1998a) demonstrated that in the absence of serum, insulin alone had no effect on the development of OGC and subsequent oocyte competence. The author even observed deleterious effects of the combination of insulin and $\mathrm{FSH}$ in the culture medium. Other studies using culture medium supplemented with 5\% FCS showed that the presence of insulin had no beneficial effect (Mitchell et al. 2002). In contrast, other authors showed that the association of gonadotropins and insulin was considered optimal during intact preantral follicular culture for follicular proliferation, differentiation and to generate mature oocytes (Liu et al. 2002).

During intact follicular culture in mice using a low serum concentration medium (1\%), we did not observe any difference in the follicular survival rate or the subsequent oocyte maturation rate in the presence or in the absence of insulin (Table 1).

We further evaluated the embryo development using a simplified culture medium (with 1\% FCS without insulin) compared with a control medium (with 5\% FCS and insulin). The embryo cleavage rate, obtained after in vitro growth, maturation and fertilization of oocytes from intact follicles cultured in the simplified medium was significantly reduced compared with those cultured in the control medium, without affecting the blastocyst development rate (Table 2). The total cell number per blastocyst, assessed using a double labelling staining technique, decreased when the follicles were cultured in simplified medium compared with those cultured in control medium, to the detriment of the trophectoderm cells (Table 2). The controversial results concerning the role of insulin during follicular culture could be related to the presence of other survival factors such as selenium or transferrin in the medium or to species differences.

Proliferating cells require iron, which is carried and delivered by a metal-binding glycoprotein, transferrin, with subsequent intracellular transport via the transferrin receptor. Transferrin receptors were previously described in GCs of rats and humans, with an increasing expression parallel to follicular maturation (Aleshire et al. 1989). The authors even suggested that the follicular maturation process was closely related to the high levels of cellular transferrin and of its receptor.

Sodium selenite can be added to the culture medium to activate enzymes involved in metabolic detoxification and free radical scavenging. However, the absence of sodium selenite in culture medium in mice did not significantly decrease the viability of intact preantral follicles (personal data not shown). It is important to emphasize that the action of various factors on the preantral follicular development and steroid secretion in vitro does not necessarily reflect the subsequent embryo potential.

Table 2 Cleavage and blastocyst (BI) development rates after in vitro fertilization of oocyte-cumulus complexes (OCC) obtained after in vitro preantral follicular growth using two different culture media. Intact preantral follicles were isolated from ovaries of 12-14 day-old mice and cultured in MEM supplemented with $100 \mathrm{mIU} / \mathrm{ml} \mathrm{r}-\mathrm{FSH}$, $10 \mathrm{mlU} / \mathrm{ml} \mathrm{r}-\mathrm{LH}, 5 \mu \mathrm{g} / \mathrm{ml}$ transferrin, $5 \mathrm{ng} / \mathrm{ml}$ selenium, and $5 \mu \mathrm{g} / \mathrm{ml}$ of Insulin (ITS) and 5\% fetal calf serum (FCS) (basal medium) or without insulin and $1 \%$ FCS (simplified medium). After 12 days, culture medium was replaced by maturation medium (MEM supplemented with r-FSH, r-LH, ITS, $1.5 \mathrm{IU} / \mathrm{ml} \mathrm{r-hCG,} 5 \mathrm{ng} / \mathrm{ml}$ EGF and $5 \%$ FCS). OCC were collected and fertilized with capacited sperm. Embryo were cultured in simplex optimised medium with potassium (KSOM) supplemented with $1 \mathrm{mg} / \mathrm{ml}$ of bovine serum albumin. Blastocyst cell number was evaluated using double labelling technique.

\begin{tabular}{lcc}
\hline & $\begin{array}{c}\text { Basal medium } \\
\text { with 5\% FCS }\end{array}$ & $\begin{array}{c}\text { Simplified medium with } \\
\mathbf{1 \%} \text { FCS and no insulin }\end{array}$ \\
\hline$n$ (OCC) & 242 & 208 \\
2-cells/OCC (\%) & $113(46.7)^{\mathrm{a}}$ & $77(37)^{\mathrm{b}}$ \\
$\mathrm{B} 1 / 2$-cells 120h (\%) & $54(47.8)$ & $39(50.6)$ \\
$n$ (blastocyst) & 44 & 32 \\
TE (range) & $27.9 \pm 1.08^{\mathrm{a}}(13-42)$ & $22.9 \pm 1.4^{\mathrm{b}}(7-41)$ \\
ICM (range) & $17 \pm 0.7(8-27)$ & $17.6 \pm 1.06(8-31)$ \\
Total (range) & $45.1 \pm 1.7^{\mathrm{c}}(24-68)$ & $39.9 \pm 2.49^{\mathrm{d}}(21-65)$ \\
\hline
\end{tabular}

a vs b, c vs d: $P<0.05$.

$\mathrm{TE}$, trophectoderm; ICM, inner cell mass. 


\section{Paracrine factors}

Since the last decade, many peptides interacting with the follicular growth and cell differentiation during in vitro culture of preantral follicles have been identified (Table 3).

Some factors such as tumor necrosis factor- $\alpha$ (TNF- $\alpha$ ), or interleukin-6 (Il-6) have been shown to promote apoptosis and therefore have negative effects on in vitro follicular development (Chun \& Hsueh 1998). During in vitro culture of early antral rat follicles, the addition of TNF- $\alpha$ suppressed the antiapoptotic effect of FSH in a dose dependent manner (Kaipia et al. 1996).

Other factors have also been shown to induce a negative effect on in vitro follicular development. GCs, theca cells and interstitial cells have specific receptors for leptin, the hormone of the obese gene, inducing an inhibition of steroid production and cellular proliferation during $\mathrm{FSH}$ dependant follicular growth (Kikuchi et al. 2001). Administration of leptin during preantral follicular culture blocked the stimulatory effect of the growth hormone $(\mathrm{GH})$ and the IGF-I on GC proliferation. The leptin inhibitory effect on steroid production has also been observed using rat and human GCs culture in the presence of FSH and IGF-I (Zachow \& Magoffin 1997, Agarwal et al. 1999). Other extraovarian factors have receptors in somatic and germ cells and can directly influence the reproductive function. Thyroid dysfunction is frequently involved in infertility. The mouse preantral follicle culture system was used to assess the influence of 3,3',5-triiodothyronine $\left(T_{3}\right)$ during early folliculogenesis. In the presence of $\mathrm{FSH}, \mathrm{T}_{3}$ inhibited the follicle's ability to form an antral cavity, reduced the estradiol release and affected the oocyte meiotic competence (Cecconi et al. 2004).

The transforming growth factor- $\beta$ (TGF- $\beta$ ) superfamily includes different factors such as activin, inhibin, growth differentiation factor-9 (GDF-9), BMPs or the anti-müllerian hormone $(\mathrm{AMH})$ that influence follicular development (Lin et al. 2003). The pattern of $\mathrm{AMH}$ expression in the ovary is comparable in humans and mice, and was observed in the GCs from the primary to the early antral follicular stage (Weenen et al. 2004). This hormone regulates the cyclic recruitment of preantral follicles. $\mathrm{AMH}$ deficient female mice have an increased number of growing follicles in spite of a lower serum FSH level (Durlinger et al. 1999). During in vitro mice preantral follicular culture, the presence of $\mathrm{AMH}$ suppressed the stimulatory effect of FSH (Durlinger et al. 2001). In contrast, $\mathrm{AMH}$ was also reported to enhance $\mathrm{FSH}$ stimulatory effect of rat preantral follicles (McGee et al. 2001). These contradictory results were not clearly explained and could be due to serum factors influencing the $\mathrm{AMH}$ effect.

GDF-9 and BMP-15 are expressed by oocytes from primary to antral follicles and play an essential role in the initial follicular recruitment. Both GDF-9 and BMP-15 are able to stimulate GCs proliferation in preantral follicles, through an FSH dependent mechanism (Hayashi et al. 1999, Shimasaki et al. 2004). Added during rat GCs culture in the presence of FSH, BMP-4 and BMP-7, they induced an increase in estradiol production and a decrease in progesterone production. BMPs seem to play an important role in modulating the FSH action and in avoiding premature luteinization (review by Shimasaki et al. 2004). Paracrine factors secreted by the GCs also regulate many aspects of early folliculogenesis. Among them, the proto-oncogene c-kit, encoded at the white spotting (W) locus in the oocyte and its product $K L$, encoded at the steel locus (SI) in the GCs appeared to be one of the key factors of the follicular growth initiation. However, Kit-KL interaction also operates throughout preantral and antral follicular growth and differentiation. Both KL and leukemia inhibitory factor (LIF) act on the oocyte to modulate its survival and maturation at the meiotic stage. Added during preantral follicle culture, $\mathrm{KL}$ stimulated the production of testosterone as well as GCs proliferation and oocyte maturation (Reynaud et al. 2000).

Activin A has been shown to enhance GCs proliferation during in vitro rat OGC culture (Li et al. 1995). During antral follicular development, activin A induces a dose dependent suppression of apoptosis DNA fragmentation (Chun \& Hsueh 1998). Activin A also acts as a regulator in the progression of the cohort of small follicles through the later stage. The presence of activin $\mathrm{A}$ inhibits the stimulatory effect of $\mathrm{FSH}$ and $\mathrm{GH}$ in a reversible way during culture of small preantral follicles isolated from adult mice ovaries (Mizunuma et al. 1999). Moreover, the authors demonstrated that activin $\mathrm{A}$ is the factor secreted by secondary follicles responsible for the maintenance of small preantral follicles at a dormant stage. In contrast, using coculture across polycarbonate membrane, Spears et al. (2002) did not identify activin A as an inhibitory factor secreted by dominant follicles. Those contradictory results may be due to the difference of age of the mice and of the developmental stage of the follicles selected for culture.

Other factors identified in the ovary were shown to promote preantral follicular development in vitro. Functional receptors for EGF and TGF- $\alpha$, an EGF analogue, are expressed in the ovary and have been shown to be upregulated by gonadotropins (Fujinaga et al. 1994). However, both EGF and TGF $\alpha$ have been described as potent inhibitors of aromatization in cultured GCs in humans and during in vitro growth of mouse follicles (Steinkampf et al. 1988, Boland \& Gosden 1994). The physiological concentration of EGF to which mouse follicles are exposed is around $1 \mathrm{ng} / \mathrm{ml}$. The presence of EGF ranging from 1 to $20 \mathrm{ng} / \mathrm{ml}$ in the preantral follicular culture medium induced a dose-dependent decline in estradiol production (Boland \& Gosden 1994). Above a concentration of $5 \mathrm{ng} / \mathrm{ml} \mathrm{EGF}$, the number of follicles reaching the antral stage decreased. However, at physiological concentrations, EGF increased the number of follicles reaching the antral stage. Treatment of GCs and preovulatory follicles with EGF inhibited the spontaneous onset of apoptotic DNA cleavage found during culture by $40-60 \%$ 
Table 3 Effect of different growth/paracrine factors added to the culture medium during in vitro preantral follicular growth.

Culture medium supplements

\begin{tabular}{|c|c|c|c|c|c|c|c|}
\hline & Species & Protein & Survival factors & Hormone & Growth/paracrine factors & Effect of the growth/paracrine factors & References \\
\hline \multirow[t]{16}{*}{ Intact follicles } & Mouse & $5 \% \mathrm{MS}$ & ITS/IGF-I & $(\mathrm{FSH})$ & Relaxin hypoxantine dcAMP & $\begin{array}{l}\text { No effect on follicular growth and antrum } \\
\text { No effect on follicular growth } \\
\uparrow \text { follicular growth }\end{array}$ & Hartshorne et al. (1994) \\
\hline & Mouse & $5 \%$ hpgMS & $\mathrm{T}$ & FSH & EGF & $\begin{array}{l}\downarrow \text { E2 production } \\
\text { No effect on follicles diameter and DNA content }\end{array}$ & Boland \& Gosden (1994) \\
\hline & Mouse & $5 \% \mathrm{MS}$ & $\mathrm{T}$ & FSH/hCG & $\begin{array}{l}\text { EGF-Androst. } \\
\text { TGF- } \alpha\end{array}$ & $\begin{array}{l}\downarrow \text { follicular growth } \\
\downarrow \text { E2 secretion }\end{array}$ & Almahbobi et al. (1995) \\
\hline & Mouse & BSA & ITS & $(\mathrm{FSH})$ & $\begin{array}{l}\text { Activin A } \\
\text { GH } \\
\text { IGF-I }\end{array}$ & $\begin{array}{l}\uparrow \text { follicles diameter and E2 secretion } \\
\uparrow \text { effect of FSH and GH but not of IGF-I } \\
\uparrow \text { follicles diameter and E2 secretion } \\
\uparrow \text { follicles diameter when associate with FSH }\end{array}$ & Liu et al. (1998) \\
\hline & Mouse & $5 \%$ FCS & ITS & $\mathrm{FSH} / \mathrm{LH}$ & Activin A & $\begin{array}{l}\uparrow \text { inhibin secretion } \\
\downarrow \text { survival rate } \\
\downarrow \text { oocyte maturation rate }(\mathrm{FSH} 100 \mathrm{mUl} / \mathrm{ml})\end{array}$ & Smitz et al. (1998) \\
\hline & Rat & None & ITS/cGMP & $\mathrm{FSH}$ & $\begin{array}{l}\text { TNF- } \alpha \\
\|-6\end{array}$ & $\downarrow$ antiapoptotic effect of FSH & Chun \& Hsueh (1998) \\
\hline & Rat & None & ITS/cGMP & $(\mathrm{FSH})$ & GDF-9 & $\begin{array}{l}\uparrow \text { follicles diameter } \\
\uparrow \text { protein content }\end{array}$ & Hayashi et al. (1999) \\
\hline & Rat & None & ITS+/cGMP & $(\mathrm{FSH})$ & KGF & $\begin{array}{l}\downarrow \text { apoptosis } \\
\uparrow \text { follicles diameter and inhibin secretion }\end{array}$ & McGee et al. (1999) \\
\hline & Mouse & $5 \%$ FCS & ITS & FSH & Kit-ligand & $\begin{array}{l}\uparrow \text { cytoplasmic maturation } \\
\uparrow \text { GCs proliferation (if no serum) }\end{array}$ & Reynaud et al. (2000) \\
\hline & Mouse & BSA & ITS & - & Activin $\mathrm{A} / \mathrm{GH}$ & $\uparrow$ GCs and TC proliferation & Kobayashi et al. (2000) \\
\hline & Rat & None & ITS+ & $\mathrm{FSH}$ & $\begin{array}{l}\text { AMH/activin A } \\
\text { TGF- } \beta\end{array}$ & $\begin{array}{l}\uparrow \text { follicles diameter but no effect on apotosis } \\
\text { No effect on follicular diameter but } \uparrow \text { apoptosis }\end{array}$ & McGee et al. (2001) \\
\hline & Mouse & $5 \%$ IMS & - & FSH & $\mathrm{AMH}$ & $\downarrow$ stimulatory effect of FSH & Durlinger et al. (2001) \\
\hline & Mouse & BSA & ITS+ & $(\mathrm{FSH})$ & Leptin & $\downarrow$ stimulatory effect of GH and IGF-I with FSH & Kikuchi et al. (2001) \\
\hline & Rat & BSA & ITS & FSH & IGF-I & $\uparrow$ follicular diameter at a concentration up to $10 \mathrm{ng} / \mathrm{ml}$ & Zhao et al. (2001b) \\
\hline & Mouse & $1 \%$ FCS & TS & FSH & IGF-I & $\begin{array}{l}\uparrow \text { E2 secretion } \\
\uparrow \text { subsequent embroyo development }\end{array}$ & Demeestere et al. (2004) \\
\hline & Mouse & $5 \%$ FCS & ITS & FSH & $\mathrm{T}_{3}$ & $\begin{array}{l}\downarrow \text { follicles diameter and } \downarrow \text { estradiol secretion } \\
\downarrow \text { PB1 formation during oocyte maturation }\end{array}$ & Cecconi et al. (2004) \\
\hline OGC & Rat & None & IT & FSH & Activin A & $\uparrow$ follicles diameter ( $\uparrow$ GCs proliferation) & Li et al. (1995) \\
\hline
\end{tabular}

AMH, anti-mullerian hormone; MS, mouse serum; hpgMS, hypogonadal mouse serum; IMS, immature mouse serum; BSA, bovine serum albumin; ITS + , insulin, transferrin, selenium, linoleic acid; EGF, epidermal growth factor; Androst., Androstenedione; TGF- $\alpha$, transforming growth factor $\alpha$; TNF- $\alpha$, tumor necrosis factor- $\alpha$; II-6: interleukin-6; GDF-9: growth differentiation factor-9; KGF: Kerantinocyte growth factor; GH: growth hormone; IGH-I: insulin growth factor-l; $\mathrm{T}_{3}$ : thyroid hormone; GCs: granulosa cells; TE: theca cells; OGC: oocyte-granulosa-cell complexs; PB1: first polar body. Under 'Hormone' column, 'FSH' indicates experiment conducted in the presence of FSH, '(FSH)' indicates experiment conducted in absence of FSH. 
through tyrosine kinase pathways. In contrast, EGF had no effect on the suppression of apoptosis on preantral follicles (McGee et al. 1997).

Keratinocyte growth factor (KGF), also known as fibroblast growth factor-7, is a single polypeptide produced by the theca cells in rodents and bovine. The KGF receptors are expressed in GCs of growing follicles (Parrott \& Skinner 1998). Added during rat preantral follicular culture, KGF suppressed apoptosis and enhanced the GCs differentiation (McGee et al. 1999).

The intraovarian IGF system is also largely involved in the ovarian physiology. When added during in vitro culture of preantral follicles, IGF-I has been shown to stimulate follicular growth in synergy with FSH in various species (Zhou et al. 1991, Gutierrez et al. 2000, Louhio et al. 2000, Zhao et al. 2001b). In the rat, IGF-I added during in vitro preantral follicular culture increased significantly the follicular diameter, the DNA content and promoted the functional integrity of the follicles. IGF-I also stimulated steroidogenesis during mice preantral follicular culture, without any advantage on the subsequent oocyte maturation rate. However, embryo development and blastocyst cell numbers were enhanced when follicles were cultured in the presence of IGF-I and FSH (Demeestere et al. 2004). IGF binding proteins (IGFBPs) have been involved in the physiological mechanism of follicular dominance and atresia (Fortune et al. 2004). However, the expression of IGFBPs strongly varies between species. In the rat, IGFBP-4 mRNA increases during the follicular atretic process and its expression decreases in the presence of FSH during in vitro follicular culture. Furthermore, IGFBPs affinity can be modulated by phosphorylation and proteolysis. Recently, interest was focused on IGFBP-4 protease called pregnancy-associated protein A (PAPP-A). The expression of PAPP-A by the GCs of healthy follicles is stimulated by the gonadotropins (Hourvitz et al. 2002). Recently, Matsui et al. (2004) identified the oocyte derived factor BMP-15 as an inhibitor of FSH-induced PAPP-A production in vitro. Those experiments using the rat model confirmed other results obtained in domestic species suggesting that PAPP-A is essential for the selection of dominant follicles (Fortune et al. 2004).

\section{Conclusion}

Follicular growth and maturation are complex processes controlled by endocrine factors such as gonadotropins and locally produced factors. The reproduction of the whole follicular development in vitro constitutes a real challenge with major potential applications in clinical practice. Progress has been made in the adaptation of the follicular culture medium since the last decade in rodents, mammals and humans. However, the mouse is the only species where offspring were obtained after in vitro growth, maturation and fertilization of oocytes from the primordial stage. This species constitutes an efficient model to assess the effects of the different in vitro components on the follicular development and to improve our knowledge on folliculogenesis.

\section{Acknowledgements}

This study was supported by the Belgian National Fund for Scientific Research (FNRS). I D is 'Collaborateur Scientifique' of the FNRS.

\section{References}

Abel MH, Wootton AN, Wilkins V, Huhtaniemi I, Knight PG \& Charlton HM 2000 The effect of a null mutation in the follicle-stimulating hormone receptor gene on mouse reproduction. Endocrinology 141 1795-1803.

Adriaens I, Cortvrindt R \& Smitz J 2004 Differential FSH exposure in preantral follicle culture has marked effects on folliculogenesis and oocyte developmental competence. Human Reproduction 19 $398-408$

Agarwal SK, Vogel K, Weitsman SR \& Magoffin DA 1999 Leptin antagonizes the insulin-like growth factor-I augmentation of steroidogenesis in granulosa and theca cells of the human ovary. Journal of Clinical Endocrinology and Metabolism 84 1072-1076.

Albertini DF, Combelles CM, Benecchi E \& Carabatsos MJ 2001 Cellular basis for paracrine regulation of ovarian follicle development. Reproduction 121 647-653.

Aleshire SL, Osteen KG, Maxson WS, Entman SS, Bradley CA \& Parl FF 1989 Localization of transferrin and its receptor in ovarian follicular cells: morphologic studies in relation to follicular development. Fertility and Sterility 51 444-449.

Almahbobi G, Nagodavithane A \& Trounson AO 1995 Effects of epidermal growth factor, transforming growth factor alpha and androstenedione on follicular growth and aromatization in culture. Human Reproduction 10 2767-2772.

Ashkenazi H, Cao X, Motola S, Popliker M, Conti M \& Tsafriri A 2005 Epidermal growth factor family members: endogenous mediators of the ovulatory response. Endocrinology 146 77-84.

Boland NI \& Gosden RG 1994 Effects of epidermal growth factor on the growth and differentiation of cultured mouse ovarian follicles. Journal of Reproduction and Fertility 10 369-374.

Cecconi S, Rossi G, Coticchio G, Macchiarelli G, Borini A \& Canipari R 2004 Influence of thyroid hormone on mouse preantral follicle development in vitro. Fertility and Sterility 81 919-924.

Chun SY \& Hsueh AJ 1998 Paracrine mechanisms of ovarian follicle apoptosis. Journal of Reproductive Immunology 39 63-75.

Chun SY, Billig H, Tilly JL, Furuta I, Tsafriri A \& Hsueh AJW 1994 Gonadotropin suppression of apoptosis in cultured preovulatory follicles: mediatory role of endogenous insulin-like growth factor I. Endocrinology 135 1845-1853.

Cortvrindt RG \& Smitz JE 2002 Follicle culture in reproductive toxicology: a tool for in vitro testing of ovarian function? Human Reproduction Update 8 243-254.

Cortvrindt R, Smitz J \& Van Steirteghem AC 1996 In vitro maturation, fertilization and embryo development of immature oocytes from early preantral follicles from prepuberal mice in a simplified culture system. Human Reproduction 11 2656-2666.

Cortvrindt R, Smitz J \& Van Steirteghem AC 1997 Assessment of the need for follicle stimulating hormone in early preantral mouse follicle culture in vitro. Human Reproduction 12 759-768.

Cortvrindt R, Hu Y \& Smitz J 1998 Recombinant luteinizing hormone as a survival and differentiation factor increases oocyte maturation in recombinant follicle stimulating hormone-supplemented mouse preantral follicle culture. Human Reproduction $131292-1302$. 
Demeestere I, Delbaere A, Gervy C, Van Den Bergh M, Devreker F \& Englert Y 2002 Effect of preantral follicle isolation technique on in vitro follicular growth, oocyte maturation and embryo development in mice. Human Reproduction 17 2152-2159.

Demeestere I, Simon P, Englert Y \& Delbaere A 2003 Preliminary experience of ovarian tissue cryopreservation procedure: alternatives, perspectives and feasibility. Reproduction Biomedicine Online 7 572-579.

Demeestere I, Gervy C, Centner J, Devreker F, Englert Y \& Delbaere A 2004 Effect of insulin-like growth factor-I during preantral follicular culture on steroidogenesis, in vitro oocyte maturation, and embryo development in mice. Biology of Reproduction $\mathbf{7 0}$ $1664-1669$.

Durlinger AL, Kramer P, Karels B, de Jong FH, Uilenbroek JT, Grootegoed JA \& Themmen AP 1999 Control of primordial follicle recruitment by anti-Mullerian hormone in the mouse ovary. Endocrinology 140 5789-5796.

Durlinger AL, Gruijters MJ, Kramer P, Karels B, Kumar TR, Matzuk MM, Rose UM, de Jong FH, Uilenbroek JT, Grootegoed JA \& Themmen AP 2001 Anti-Mullerian hormone attenuates the effects of FSH on follicle development in the mouse ovary. Endocrinology 142 4891-4899.

Eppig JJ \& Schroeder AC 1989 Capacity of mouse oocytes from preantral follicles to undergo embryogenesis and development to live young after growth, maturation, and fertilization in vitro. Biology of Reproduction 41 268-276.

Eppig JJ, O'Brien M \& Wigglesworth K 1996a Mammalian oocyte growth and development in vitro. Molecular Reproduction and Development 44 260-273.

Eppig JJ \& O'Brien MJ 1996 Development in vitro of mouse oocytes from primordial follicles. Biology of Reproduction 54 197-207.

Eppig JJ, O'Brien MJ, Pendola FL \& Watanabe S 1998a Factors affecting the developmental competence of mouse oocytes grown in vitro: follicle-stimulating hormone and insulin. Biology of Reproduction 59 1445-1453.

Eppig JJ \& O'Brien MJ 1998b Comparison of preimplantation developmental competence after mouse oocyte growth and development in vitro and in vivo. Theriogenology 49 415-422.

Eppig JJ, Hosoe M, O'Brien MJ, Pendola FM, Requena A \& Watanabe S 2000 Conditions that affect acquisition of developmental competence by mouse oocytes in vitro: $\mathrm{FSH}$, insulin, glucose and ascorbic acid. Molecular and Cellular Endocrinology 163 109-116.

Erickson GF \& Shimasaki S 2001 The physiology of folliculogenesis: the role of novel growth factors. Fertility and Sterility 76 943-949.

Fortune JE, Rivera GM \& Yang MY 2004 Follicular development: the role of the follicular microenvironment in selection of the dominant follicle. Animal Reproduction Science 82-83 109-126.

Fujinaga H, Yamoto M, Shikone T \& Nakano R 1994 FSH and LH up-regulate epidermal growth factor receptors in rat granulosa cells. Journal of Endocrinology 140 171-177.

Gosden RG, Boland NI, Spears N, Murray AA, Chapman M, Wade JC \& Zohdy NI 1993 The biology and technology of follicular oocyte development in vitro. Reproductive Medicine Review 2 $129-152$.

Gougeon A 1996 Regulation of ovarian follicular development in primates: facts and hypotheses. Endocrine Review 17 121-155.

Guthrie HD, Garrett WM \& Cooper BS 1998 Follicle-stimulating hormone and insulin-like growth factor-I attenuate apoptosis in cultured porcine granulosa cells. Biology of Reproduction $\mathbf{5 8}$ 390-396.

Gutierrez CG, Campbell BK \& Webb R 1997 Development of a long-term bovine granulosa cell culture system: induction and maintenance of estradiol production, response to follicle-stimulating hormone, and morphological characteristics. Biology of Reproduction $\mathbf{5 6} 608-616$.

Gutierrez CG, Ralph JH, Telfer EE, Wilmut I \& Webb R 2000 Growth and antrum formation of bovine preantral follicles in longterm culture in vitro. Biology of Reproduction 62 1322-1328.
Hardy K, Wright C, Rice S, Tachataki M, Roberts R, Morgan D, Spanos S \& Taylor D 2002 Future developments in assisted reproduction in humans. Reproduction 123 171-183.

Hartshorne GM, Sargent IL \& Barlow DH 1994 Growth rates and antrum formation of mouse ovarian follicles in vitro in response to follicle-stimulating hormone, relaxin, cyclic AMP and hypoxanthine. Human Reproduction 9 1003-1012.

Hayashi M, McGee EA, Min G, Klein C, Rose UM, van Duin M \& Hsueh AJ 1999 Recombinant growth differentiation factor-9 (GDF9) enhances growth and differentiation of cultured early ovarian follicles. Endocrinology 140 1236-1244.

Hourvitz A, Kuwahara A, Hennebold JD, Tavares AB, Negishi H, Lee TH, Erickson GF \& Adashi EY 2002 The regulated expression of the pregnancy-associated plasma protein-A in the rodent ovary: a proposed role in the development of dominant follicles and of corpora lutea. Endocrinology 143 1833-1844.

Hu Y, Cortvrindt R \& Smitz J 2002 Effects of aromatase inhibition on in vitro follicle and oocyte development analyzed by early preantral mouse follicle culture. Molecular Reproduction and Development 61 549-559.

Hsueh AJ, Billig H \& Tsafriri A 1994 Ovarian follicle atresia: a hormonally controlled apoptotic process. Endocrine Reviews $\mathbf{1 5}$ 707-724.

Kaipia A, Chun SY, Eisenhauer K \& Hsueh AJ 1996 Tumor necrosis factor-alpha and its second messenger, ceramide, stimulate apoptosis in cultured ovarian follicles. Endocrinology 137 4864-4870.

Kikuchi N, Andoh K, Abe Y, Yamada K, Mizunuma H \& Ibuki Y 2001 Inhibitory action of leptin on early follicular growth differs in immature and adult female mice. Biology of Reproduction 65 66-71.

Kobayashi J, Mizunuma H, Kikuchi N, Liu X, Andoh K, Abe $\mathrm{Y}$, Yokota H, Yamada K, Ibuki Y \& Hagiwara H 2000 Morphological assessment of the effect of growth hormone on preantral follicles from 11-day-old mice in an in vitro culture system. Biochemical and Biophysical Research Communication 268 36-41.

Kumar TR, Wang Y, Lu N \& Matzuk MM 1997 Follicle stimulating hormone is required for ovarian follicle maturation but not male fertility. Nature Genetics 15 201-204.

LaPolt PS, Tilly JL, Aihara T, Nishimori K \& Hsueh AJ 1992 Gonadotropin-induced up- and down-regulation of ovarian follicle-stimulating hormone $(\mathrm{FSH})$ receptor gene expression in immature rats: effects of pregnant mare's serum gonadotropin, human chorionic gonadotropin, and recombinant FSH. Endocrinology 130 1289-1295.

Li R, Phillips D \& Mather JP 1995 Activin promotes ovarian follicle development in vitro. Endocrinology 136 849-856.

Lin SY, Morrison JR, Phillips D \& de Kretser DM 2003 Regulation of ovarian function by the TGF-beta superfamily and follistatin. Reproduction 126 133-148.

Liu HC, He Z \& Rosenwaks Z 2002 In vitro culture and in vitro maturation of mouse preantral follicles with recombinant gonadotropins. Fertility and Sterility 77 373-383.

Liu X, Andoh K, Yokota H, Kobayashi J, Abe Y, Yamada K, Mizunuma H \& Ibuki Y 1998 Effects of growth hormone, activin, and follistatin on the development of preantral follicle from immature female mice. Endocrinology 139 2342-2347.

Liu X, Andoh K, Mizunuma H, Kamijo T, Kikuchi N, Yamada K \& Ibuki Y 2000 Effects of recombinant human FSH (rhFSH), urinary purified FSH (uFSH), and hMG on small preantral follicles and tertiary follicles from normal adult and androgen-sterilized female mice. Fertility and Sterility 73 372-380.

Louhio H, Hovatta O, Sjoberg J \& Tuuri T 2000 The effects of insulin, and insulin-like growth factors I and II on human ovarian follicles in long-term culture. Molecular Human Reproduction 6 694-698.

Ma X, Dong Y, Matzuk MM \& Kumar TR 2004 Targeted disruption of luteinizing hormone beta-subunit leads to hypogonadism, defects in gonadal steroidogenesis, and infertility. PNAS 101 17294-17299. 
Mao J, Wu G, Smith MF, McCauley TC, Cantley TC, Prather RS, Didion BA \& Day BN 2002 Effects of culture medium, serum type, and various concentrations of follicle-stimulating hormone on porcine preantral follicular development and antrum formation in vitro. Biology of Reproduction 67 1197-1203.

Matsui M, Sonntag B, Soo Hwang S, Byerly T, Hourvitz A, Adashi EY, Shimasaki S \& Erickson GF 2004 Pregnancy-Associated Plasma Protein-A (PAPP-A) production in rat granulosa cells: stimulation by follicle stimulating hormone and inhibition by the oocyte-derived bone morphogenetic protein-15. Endocrinology $\mathbf{1 4 5}$ 3686-3695.

McGee E, Spears N, Minami S, Hsu SY, Chun SY, Billig H \& Hsueh AJ 1997 Preantral ovarian follicles in serum-free culture: suppression of apoptosis after activation of the cyclic guanosine $3^{\prime}, 5^{\prime}$ monophosphate pathway and stimulation of growth and differentiation by follicle-stimulating hormone. Endocrinology 138 2417-2424.

McGee EA, Chun SY, Lai S, He Y \& Hsueh AJ 1999 Keratinocyte growth factor promotes the survival, growth, and differentiation of preantral ovarian follicles. Fertility and Sterility 71 732-738.

McGee EA, Smith R, Spears N, Nachtigal MW, Ingraham H \& Hsueh AJ 2001 Mullerian inhibitory substance induces growth of rat preantral ovarian follicles. Biology of Reproduction 64 293-298.

Mitchell LM, Kennedy CR \& Hartshorne GM 2002 Effects of varying gonadotrophin dose and timing on antrum formation and ovulation efficiency of mouse follicles in vitro. Human Reproduction $171181-1188$.

Mizunuma H, Liu X, Andoh K, Abe Y, Kobayashi J, Yamada K, Yokota H, Ibuki Y \& Hasegawa Y 1999 Activin from secondary follicles causes small preantral follicles to remain dormant at the resting stage. Endocrinology $14037-42$.

Murray AA, Gosden RG, Allison V \& Spears N 1998 Effect of androgens on the development of mouse follicles growing in vitro. Journal of Reproduction and Fertility $11327-33$

Murray AA, Molinek MD, Baker SJ, Kojima FN, Smith MF, Hillier SG \& Spears N 2001 Role of ascorbic acid in promoting follicle integrity and survival in intact mouse ovarian follicles in vitro. Reproduction 121 89-96.

Nayudu PL \& Osborn SM 1992 Factors influencing the rate of preantral and antral growth of mouse ovarian follicles in vitro. Journal of Reproduction and Fertility 95 349-362.

O'Brien MJ, Pendola JK \& Eppig JJ 2003 A revised protocol for in vitro development of mouse oocytes from primordial follicles dramatically improves their developmental competence. Biology of Reproduction 68 1682-1686.

Park JY, Su YQ, Ariga M, Law E, Jin SL \& Conti M 2004 EGF-like growth factors as mediators of $\mathrm{LH}$ action in the ovulatory follicle. Science $303682-684$

Parrott JA \& Skinner MK 1998 Developmental and hormonal regulation of keratinocyte growth factor expression and action in the ovarian follicle. Endocrinology 139 228-235.

Quirk SM, Harman RM \& Cowan RG 2000 Regulation of Fas antigen (Fas, CD95)-mediated apoptosis of bovine granulosa cells by serum and growth factors. Biology of Reproduction 63 $1278-1284$.

Reynaud K, Cortvrindt R, Smitz J \& Driancourt MA 2000 Effects of Kit Ligand and anti-Kit antibody on growth of cultured mouse preantral follicles. Molecular Reproduction and Development $\mathbf{5 6}$ 483-494.

Roy SK \& Greenwald GS 1985 An enzymatic method for dissociation of intact follicles from the hamster ovary: histological and quantitative aspects. Biology of Reproduction 32 203-215.

Roy SK \& Treacy BJ 1993 Isolation and long-term culture of human preantral follicles. Fertility and Sterility 59 783-790.

Shimasaki S, Moore RK, Otsuka F \& Erickson GF 2004 The bone morphogenetic protein system in mammalian reproduction. Endocrine Review 25 72-101.

Smitz J \& Cortvrindt RG 2002 The earliest stages of folliculogenesis in vitro. Reproduction 123 185-202.
Smitz J, Cortvrindt R, Hu Y \& Vanderstichele H 1998 Effects of recombinant activin A on in vitro culture of mouse preantral follicles. Molecular Reproduction and Development $\mathbf{5 0}$ 294-304.

Spears N, Baker S, Srsen V, Lapping R, Mullan J, Nelson R \& Allison V 2002 Mouse ovarian follicles secrete factors affecting the growth and development of like-sized ovarian follicles in vitro. Biology of Reproduction 67 1726-1733.

Steinkampf MP, Mendelson CR \& Simpson ER 1988 Effects of epidermal growth factor and insulin-like growth factor I on the levels of mRNA encoding aromatase cytochrome P-450 of human ovarian granulosa cells. Molecular and Cellular Endocrinology 59 93-99.

Tetsuka M, Whitelaw PF, Bremner WJ, Millar MR, Smyth CD \& Hillier SG 1995 Developmental regulation of androgen receptor in rat ovary. The Journal of Endocrinology 145 535-543.

Thomas FH, Leask R, Srsen V, Riley SC, Spears N \& Telfer EE 2001 Effect of ascorbic acid on health and morphology of bovine preantral follicles during long-term culture. Reproduction 122 487-495.

Torrance C, Telfer E \& Gosden RG 1989 Quantitative study of the development of isolated mouse pre-antral follicles in collagen gel culture. Journal of Reproduction and Fertility 87 367-374.

Wang Y, Rippstein PU \& Tsang BK 2003 Role and gonadotrophic regulation of $\mathrm{X}$-linked inhibitor of apoptosis protein expression during rat ovarian follicular development in vitro. Biology of Reproduction 68 610-619.

Weenen $C$, Laven JS, Von Bergh AR, Cranfield M, Groome NP, Visser JA, Kramer P, Fauser BC \& Themmen AP 2004 Anti-Mullerian hormone expression pattern in the human ovary: potential implications for initial and cyclic follicle recruitment. Molecular Human Reproduction 10 77-83.

Yacobi K, Wojtowicz A, Tsafriri A \& Gross A 2004 Gonadotropins enhance caspase- 3 and -7 activity and apoptosis in the theca-interstitial cells of rat preovulatory follicles in culture. Endocrinology $1451943-1951$.

Yang MY \& Rajamahendran R 2000 Morphological and biochemical identification of apoptosis in small, medium, and large bovine follicles and the effects of follicle-stimulating hormone and insulin-like growth factor-I on spontaneous apoptosis in cultured bovine granulosa cells. Biology of Reproduction 62 $1209-1217$.

Zachow RJ \& Magoffin DA 1997 Direct intraovarian effects of leptin: impairment of the synergistic action of insulin-like growth factor-I on follicle-stimulating hormone-dependent estradiol-17 beta production by rat ovarian granulosa cells. Endocrinology 138 847-850.

Zhang FP, Poutanen M, Wilbertz J \& Huhtaniemi I 2001 Normal prenatal but arrested postnatal sexual development of luteinizing hormone receptor knockout (LuRKO) mice. Molecular Endocrinology 15 172-183.

Zhao J, Taverne MA, van der Weijden GC, Bevers MM \& van den Hurk R 2001a Effect of activin A on in vitro development of rat preantral follicles and localization of activin A and activin receptor II. Biology of Reproduction 65 967-977.

Zhao J, Taverne MA, Van Der Weijden GC, Bevers MM \& Van Den Hurk R 2001b Insulin-like growth factor-I (IGF-I) stimulates the development of cultured rat pre-antral follicles. Molecular Reproduction and Development 58 287-296.

Zhou J, Chin E \& Bondy C 1991 Cellular pattern of insulin-like growth factor-I (IGF-I) and IGF-I receptor gene expression in the developing and mature ovarian follicle. Endocrinology 129 $3281-3288$.

Received 14 January 2005

First decision 22 February 2005

Revised manuscript received 30 March 2005

Accepted 26 April 2005 